\title{
Ultrastructure of the Mouse Epididymal Duct with Special Reference to the Regional Differences of the Principal Cells*
}

\author{
Kazuhiro ABE, Hiroko TAKANo and Takashi ITo \\ Department of Anatomy (Prof. T. ITo), Hokkaido University School of Medicine, Sapporo, Japan
}

Received April 22, 1982

Summary. It is generally known that spermatozoa aquire the capacity for fertilization during passage through the proximal region of the epididymal duct and are then stored in the distal region of the duct (BEDFORD, 1975; HAMILTON, 1975). The mouse epididymal duct has been divided into five segments (I-V) by light microscopy ; Segments I, II ard III constitute the head of the epididymis, Segment IV the body, and Segment $V$ the tail ; Segments I, II and III seem to belong to the proximal region, and Segments IV and V to the distal region (TAKANO, 1980). In this electron microscope study, we have examined the regional differences of the principal cells of the epididymal duct to understand the functional significance of each segment.

The principal cells decrease in height distalwards from Segments I to V. The nucleus is situated basally in the cells, with a well developed Golgi apparatus located above it. The endoplasmic reticulum in Segments I, II and III is generally vesicular, and is distributed throughout the cytoplasm. The ribosomes attached to the endoplasmic reticulum increase in number from Segments I to III. In Segments IV and V, flattened rough endoplasmic reticulum is seen in the basal cytoplasm of the cells. The multivesicular bodies are usually located in the supranuclear cytoplasm. They are large in Segment II and frequent in Segments II and IV. The dense bodies are specific in appearance for the cells in each segment. They are seen in the supranuclear cytoplasm in Segment $I$ and in the infranuclear cytoplasm in Segments III, IV and V. Few dense bodies are found in Segment II. The apical cytoplasm contains coated and non-coated vesicles. These vesicles consist of large and small types in Segments I, II and III. They are of the small type in Segments IV and V. The luminal surface membrane has coated or non-coated invaginations between stereocilia.

The findings suggest that the principal cells have secretory and absorptive functions specific for each segment. Discussion shall be made on the possibility that the secretion of the specific epididymal substances may provide the fertilizing ability to spermatozoa and the absorption pertains to the testicular fluid, epididymal secretions and substances bound to spermatozoa.

The epididymis is composed of a highly tortuous duct which is considered to be functionally concerned with the maturation and storage of spermatozoa (see reviews by BedFord, 1975; Hamilton, 1975). The epididymal duct can morphologically be divided *This study was supported by a grant from the Ministry of Education, 1981 (56770002). 


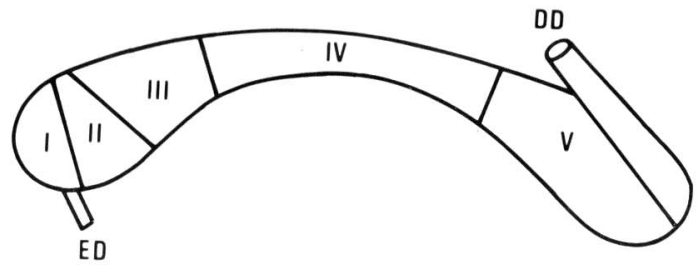

Fig. 1. Diagram of the mouse epididymis, which is composed of five segments (I-V) of the epididymal duct. ED efferent duct, $D D$ deferent duct.

into a number of segments which are thought to vary functionally as well (see reviews by Glover and NicANDER, 1971; Bedford, 1975; Hamilton, 1975). The segments of the duct vary in number according to the animal species (Reid and Cleland, 1957; Nicander, 1957, 1958; Holstein, 1969; NicAndeR and Glover, 1973; Hoffer and GreenBERG, 1978). In the mouse, we have previously divided the epididymal duct by light microscopy into five segments (I-V) according to qualitative and quantitative morphological differences (TAKANO, 1980). Segments I, II and III constitute the head of the epididymis, Segment IV forms the body, and Segment V the tail (Fig. 1). Furthermore, the finding that the segments react differently to the ligation of the duct at various levels has suggested that the duct is functionally different in the different segments (TAKANo et al., 1981; ABE et al., 1982a, b). In the mouse, however, little information has been available about the regional difference in the ultrastructure of the epididymal duct. In this study, we have examined the ultrastructure of the principal cells primarily constituting the epithelium for each segment in relation to their functional significance.

\section{MATERIALS AND METHODS}

Twenty-four male dd-mice were used. The epididymis was fixed with $5 \%$ formol or $3 \%$ paraformaldehyde- $1 \%$ glutaraldehyde in $0.1 \mathrm{M}$ cacodylate buffer $(\mathrm{pH} 7.4)$ for $2 \mathrm{hrs}$, postfixed with $2 \% \mathrm{OsO}_{4}$ for $2 \mathrm{hrs}$, and embedded in Epon. Ultrathin sections were stained with uranyl acetate and lead citrate, and examined qualitatively and quantitatively by electron microscopy.

For the quantitative examination, the principal cells showing the lateral profile from the basal to luminal surface were randomly photographed at a magnification of 2,000 or 3,000 times and enlarged in prints to 6,000 to 9,000 times. The multivesicular bodies or dense bodies in the cells were counted in the cytoplasm above and below the level of the nucleus. For quantitation of the vesicles and the invaginations of the luminal cell membrane in the apical cytoplasm, the number and size of the vesicles and invaginations were obtained on electron micrographs enlarged at a magnification of 20,000 times. In addition, the ultrastructure of the principal cells was schematically presented not only qualitatively but also quantitatively.

\section{RESULTS}

The epididymal duct is lined with a columnar epithelium which is mainly composed of principal cells with stereocilia-long microvilli-on the luminal surface (Fig. 2, 3). The lumen of the duct increases in diameter distalwards from Segments I to V. Spermatozoa contained in the lumen are sparse in Segment I, but they increase in number distalwards.

The principal cells decrease in height and increase in width proceeding distally; 
they are about $50 \mu \mathrm{m}$ in height and $6 \mu \mathrm{m}$ in width in Segment I, and about $15 \mu \mathrm{m}$ in height and $12 \mu \mathrm{m}$ in width in Segment V. The principal cells are varied in ultrastructural details in the different segments (Fig. 2, 3). The microvilli are about $20 \mu \mathrm{m}$ in length in Segment I, and they decrease distally in length, to about $3 \mu \mathrm{m}$ in Segment. V.

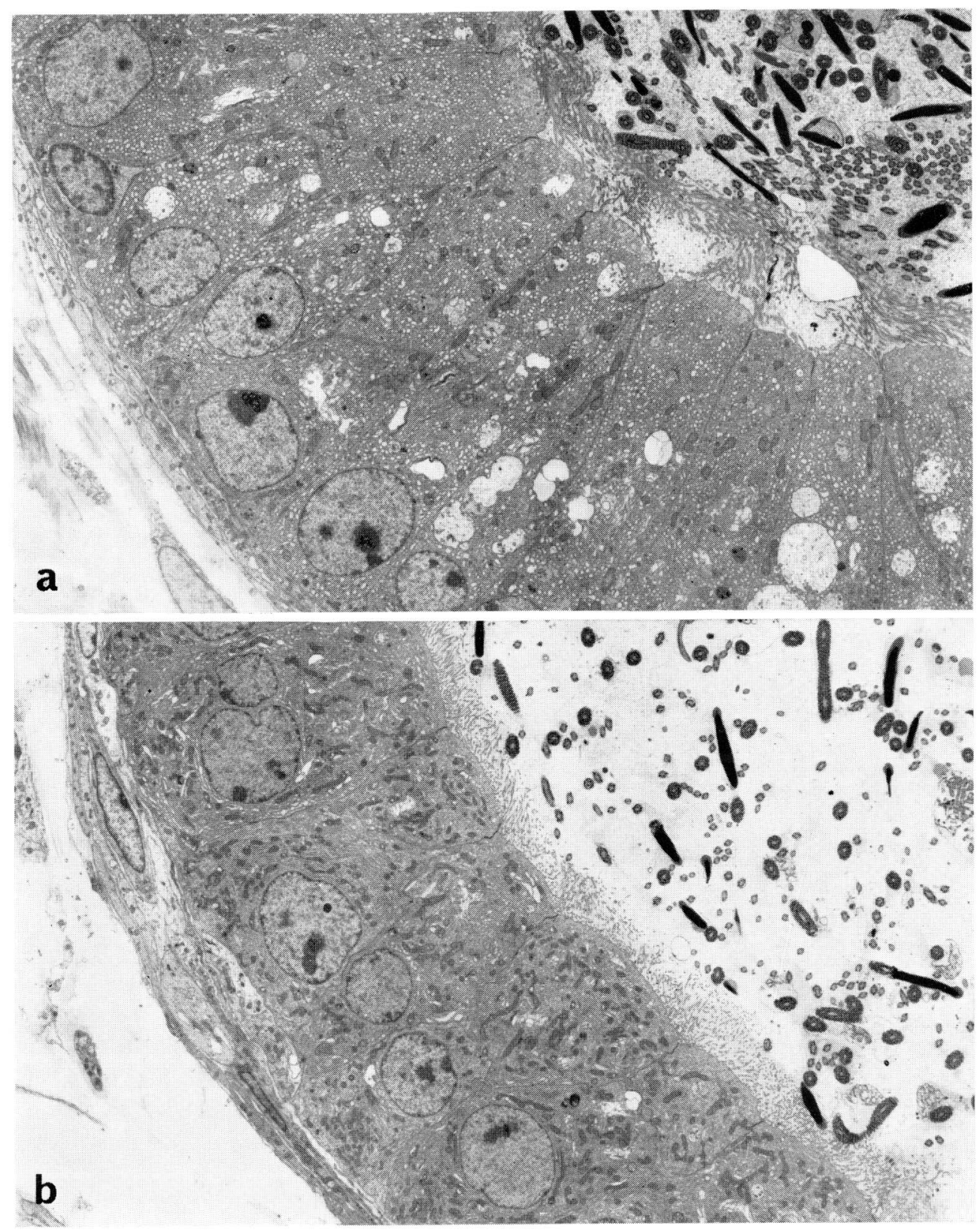

Fig. 2. a and b. Epididymal duct in Segments II (a) and IV (b). The lumen (upper right) contains abundant spermatozoa. The duct is lined by principal cells with stereocilia. The principal cells in Segments II and IV differ in height and ultrastructural details. The nuclei of the principal cells are situated basally. $\times 2,000$ 


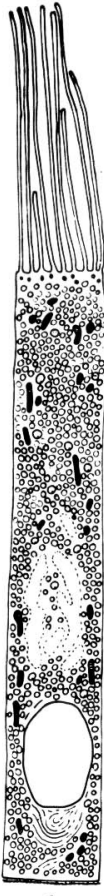

1

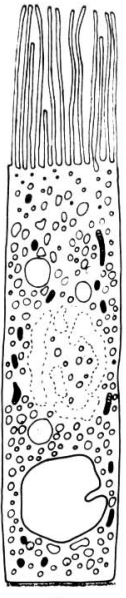

2

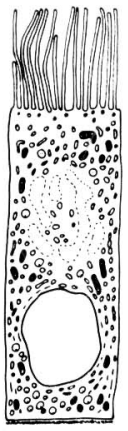

3

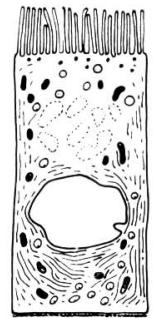

4

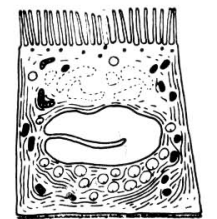

5

Fig. 3. Diagram showing the features of the principal cells in Segments I to V (1-5) of the epididymal duct. The cell width and height, nucleus size, and length of the stereocilia in this diagram are proportional to the mean values measured in each segment. A Golgi apparatus is closed by dotted lines. The Golgi area is located above the nucleus. The cytoplasm is filled with well developed organelles.

The nucleus is generally situated basally in the cell. In Segment I the nucleus is long and elliptical with a long diameter parallel to the cell axis. In Segments II, III and IV, the nucleus is round or oval with a diameter of about $6 \mu \mathrm{m}$. The nucleus is slightly flattened in Segment V. A well developed Golgi apparatus is seen above the nucleus, forming a marked Golgi area which is almost as large as the nucleus. Mitochondria are generally elongated in shape and scattered throughout the cytoplasm.

Endoplasmic reticulum (Fig. 4-7): The principal cells in Segment I are very abundant in vesicular endoplasmic reticulum about $0.2 \mu \mathrm{m}$ in diameter, which is densely distributed throughout the cytoplasm (Fig. 4a, 6,7). The vesicular endoplasmic reticulum is rarely studded with ribosomes (Fig. 4a). Below the nucleus are the flattened cisterns of rough endoplasmic reticulum which frequently form concentric lamellae (Fig. 5a, 6). In Segment II the elements of endoplasmic reticulum are also abundant and distributed, though less densely than in Segment I, throughout the cytoplasm (Fig. 4b, 6). The endoplasmic reticulum is vesicular, varying in size, though generally larger than that in Segment I, and occasionally contains vesicles invaginating from the limiting membrane (Fig. 4b, 6, 7). The limiting membrane is studded with a small number of ribosomes (Fig. 4b, 6). Flattened rough endoplasmic reticulum such as seen in Segment I is not found in Segment II. In Segment III the cisterns of rough endoplasmic reticulum 


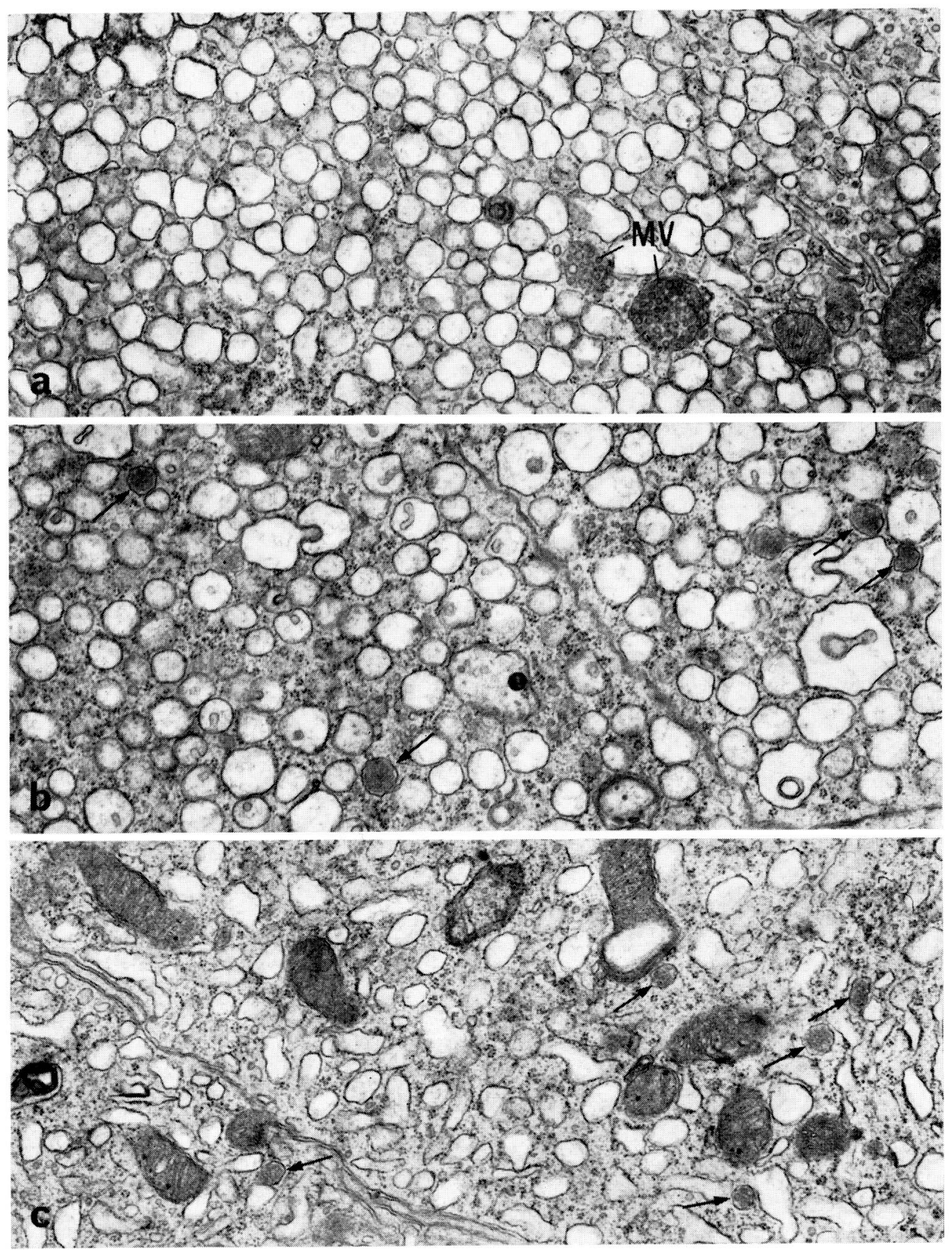

Fig. 4. Endoplasmic reticulum in the supranuclear cytoplasm of the principal cells. a. Segment I. The cytoplasm is densely packed with smooth surfaced vesicular endoplasmic reticulum showing round profiles. $M V$ multivesicular bodies. b. Segment II. The endoplasmic reticulum is vesicular, varying in size, and limited by a membrane with a small number of ribosomes. Small dense bodies with amorphous contents are scattered (arrows). c. Segment III. The endoplasmic reticulum is elongated, and bound with a membrane with ribosomes. Arrows indicate small dense bodies with amorphous contents. $\times 20,000$ 

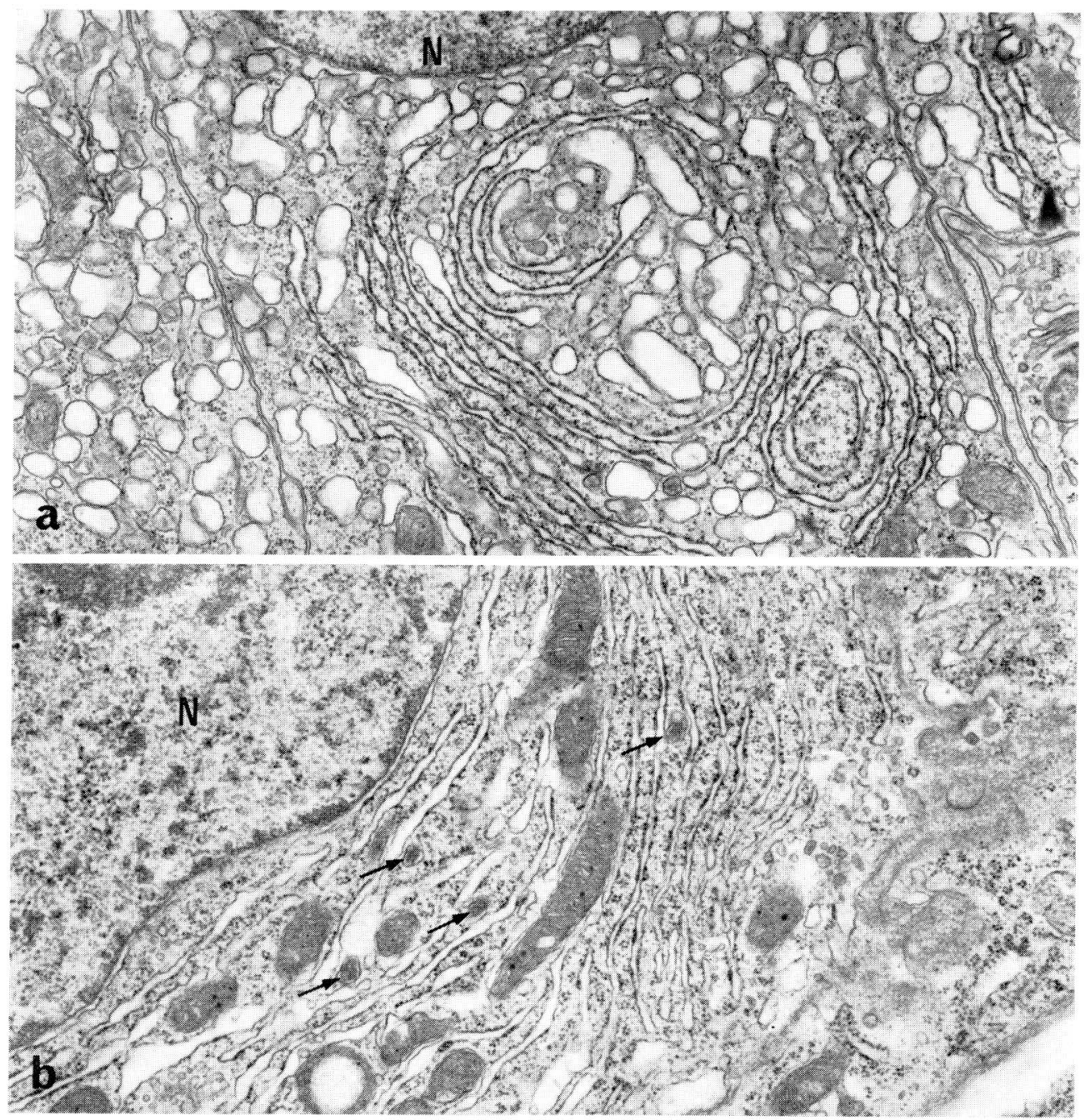

Fig. 5. Basal cytoplasm of the principal cells. $N$ nucleus. a. Segment I. Flattened rough endoplasmic reticulum forms concentric lamellae. Vesicular endoplasmic reticulum is also distributed throughout. b. Segment IV. Flattened rough endoplasmic reticulum is arranged in lamellar forms. Small dense bodies are seen (arrows). $\times 2,000$

are elongated ovals in profile and distributed throughout the cytoplasm (Fig. 4c, 6, 7). Thus the endoplasmic reticulum in Segments I, II and III is generally vesicular, and is distributed throughout the cytoplasm. The ribosomes attached to the endoplasmic reticulum increase in number distally from Segments I to III.

In Segments IV and V, the cisterns of rough endoplasmic reticulum are flattened in profile and are seen in the basal cytoplasm, around the nucleus, and along the lateral surface of the cell (Fig. 5b, 6, 7). Particularly the infranuclear cytoplasm contains a large number of rough endoplasmic reticulum which is arranged in lamellar forms (Fig. $5 b, 6)$.

Multivesicular bodies (Fig. 8-11): Multivesicular bodies are seen in the principal cells of all the segments of the epididymal duct (Fig. 8, 9). They are usually located in the 


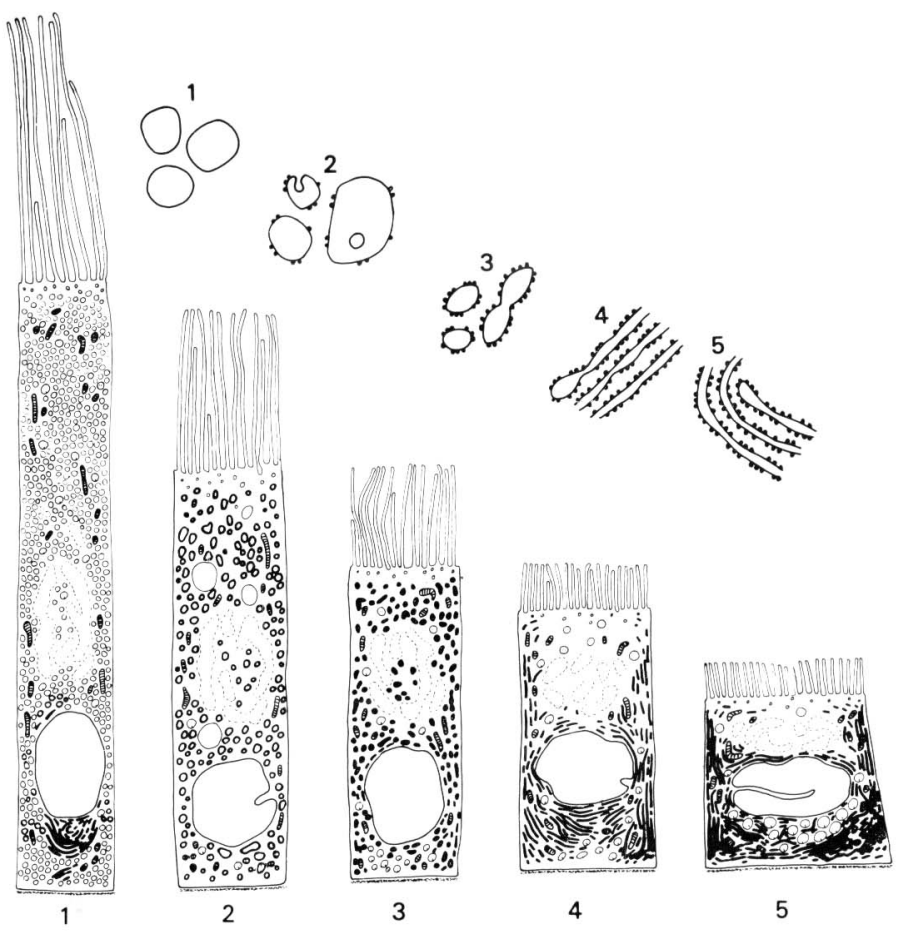

Fig. 6. Diagram showing the shape and distribution of endoplasmic reticulum in the principal cells in Segments I to $V(\mathbf{1 - 5})$. In each cell, fiattened rough endoplasmic reticulum is expressed by thick lines. Vesicular endoplasmic reticulum is expressed by open circles of thin lines (Segment I), open circles of thick lines (Segment II), and black flecks (Segment III) according to the amount of ribosomes studding the limiting membrane.

supranuclear cytoplasm, and are especially frequent in Segments II and IV (Fig. 9, 10). The multivesicular bodies are about $0.5 \mu \mathrm{m}$ in diameter in Segments I, III, IV and V, and they are twice as large in Segment II as in the other segments (Fig. 9, 11). The bodies contain varying numbers of vesicles and a matrix of variable density (Fig. 8). The large multivesicular bodies in Segment II occasionally contain a flocculent material (Fig. 8a).

Dense bodies (Fig. 12-15): Dense bodies in the principal cells show characteristic figures for each segment (Fig. 12, 13). In Segment I, they are largely distributed in the supranuclear cytoplasm (Fig. $13,14)$. The dense bodies, about $0.6 \mu \mathrm{m}$ in diameter, have various contents such as myelin figures or granules of varying sizes (Fig. 12a, 15). In Segment II, few or none of such dense bodies as seen

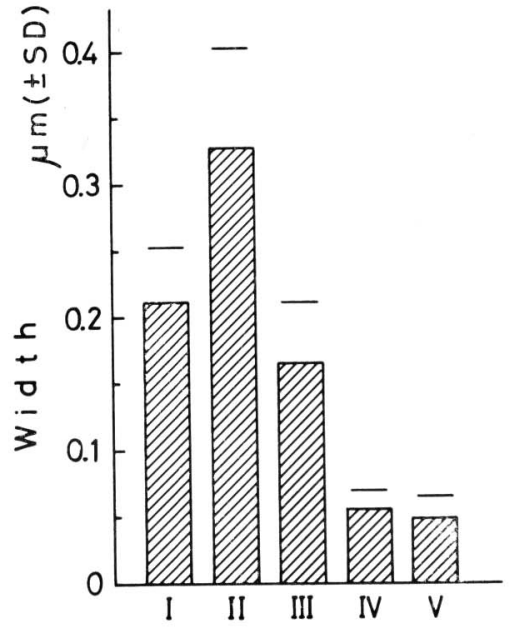

Fig. 7. Width or short diameter of the endoplasmic reticulum in the principal cells in Segments I to $\mathrm{V}$. 

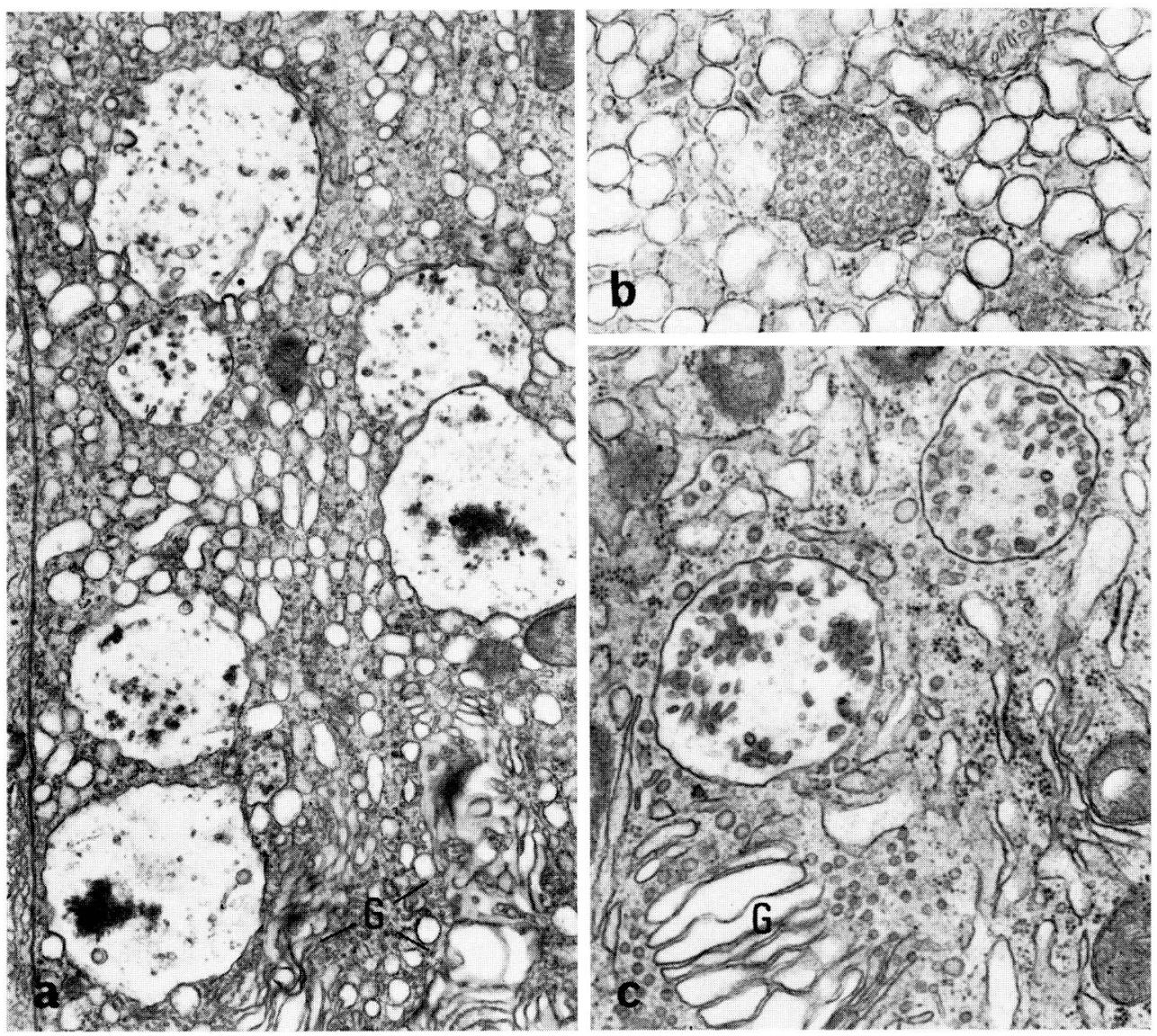

Fig. 8. Multivesicular bodies. a. Large multivesicular bodies in Segment II contain a small number of vesicles and flocculent material. G Golgi apparatus. $\times 10,000$. b. A multivesicular body in Segment I is seen in the center. $\times 27,000$. c. Two multivesicular bodies in Segment IV are shown. G Golgi apparatus. $\times 27,000$

in Segment I are seen. However, some round or irregularly-shaped dense bodies are found, about $0.5 \mu \mathrm{m}$ in diameter, which contain a flocculent material and occasional irregular small vesicles or fragmented membranous structures (Fig. 12b, 15). Intermediate forms between these dense bodies and multivesicular bodies are found. In Segment III, the dense bodies are mainly located in the basal cytoplasm (Fig. 13, 14). They often occur in clusters (Fig. 12c, d). Though varying in size, they have a mean diameter of $0.4 \mu \mathrm{m}$ (Fig. 12c, d, 15). The bodies generally contain amorphous or fine granulated material of low density (Fig. 12c, d). Particularly the smaller bodies of low density are clustered near the basal cell membrane (Fig. 12d). In Segment IV the dense bodies are usually seen in the basal cytoplasm (Fig. 12e, 13, 14). They are often arranged in clusters. They are similar in size to those in Segment III (Fig. 15). Their contents are heterogenous in appearance with amorphous or fine granulated material, granules, membranous or myelin figures, and lipid droplets (Fig. 12e). In addition to the dense bodies, there are peculiar rod-shaped inclusions, 0.3 to $0.5 \mu \mathrm{m}$ in diameter and 2 to $5 \mu \mathrm{m}$ in length, containing a bundle of tubules, $40 \mathrm{~nm}$ in diameter (Fig. 12e). The inclusions will be dealt with in detail in a separate paper (ABE et al., 1983). In Segment 
Fig. 9. Diagram showing the shape and distribution of multivesicular bodies in the principal cells in Segments I to $\mathrm{V}(\mathbf{1}-\mathbf{5})$. In each cell, multivesicular bodies are filled with black. Multivesicular bodies are located in the supranuclear cytoplasm. They are especially large in Segment II.
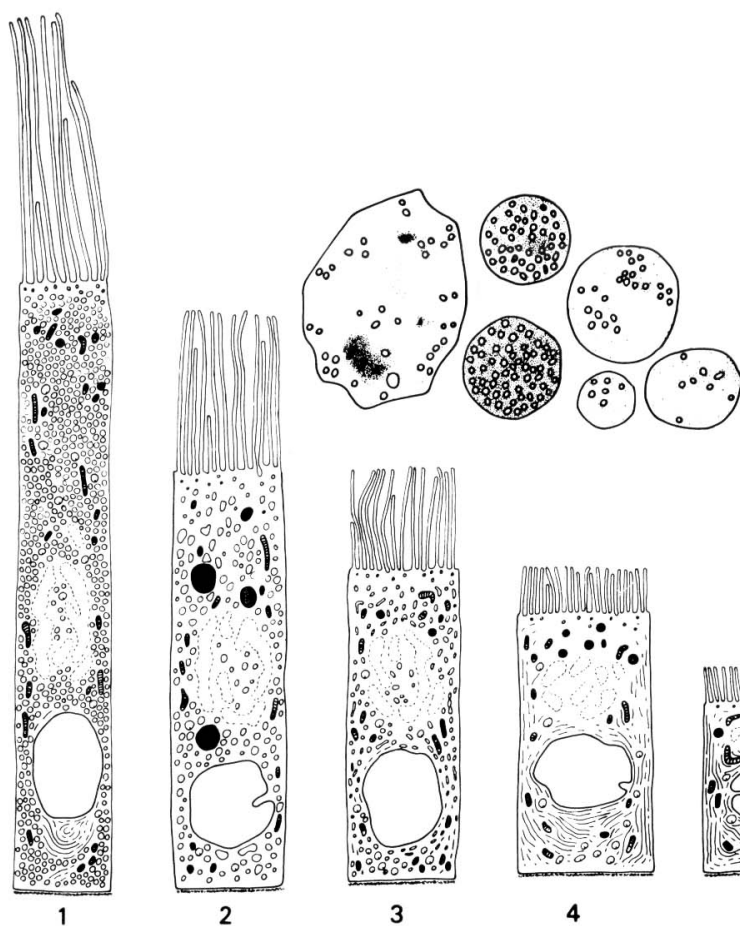

3

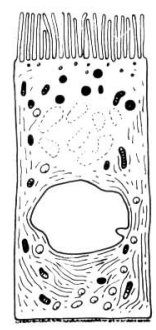

4

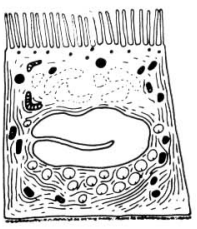

5

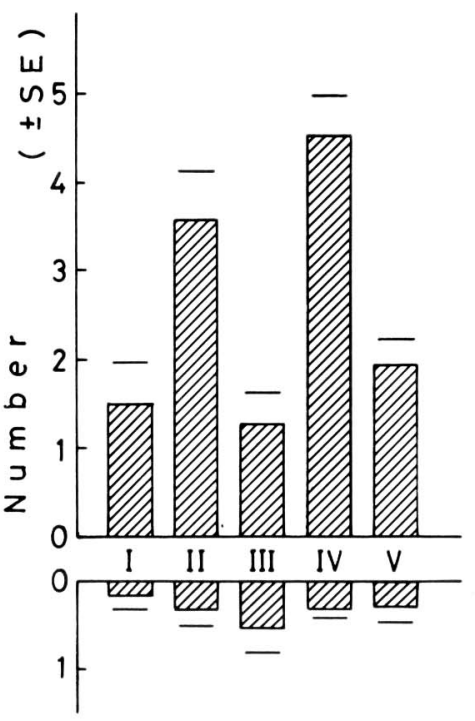

Fig. 10. Number of multivesicular bodies in the supranuclear cytoplasm (upper) and infranuclear cytoplasm (lower) of each principal cell in Segments I to V.

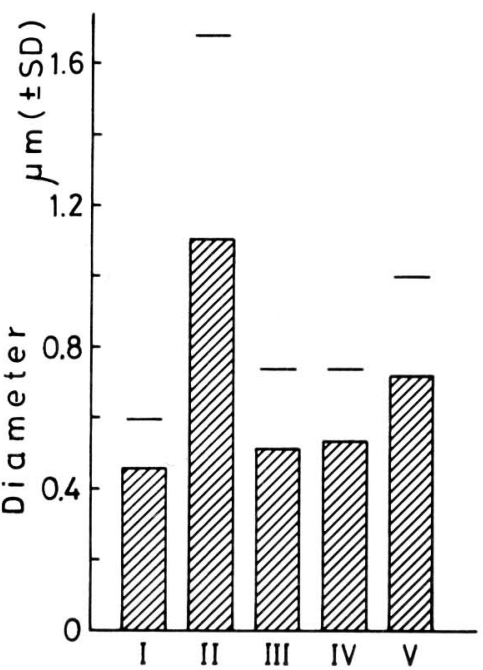

Fig. 11. Size of multivesicular bodies in the principal cells in Segments I to $\mathrm{V}$. 
$\mathrm{V}$, large dense bodies, about $0.8 \mu \mathrm{m}$ or occasionally larger than $1 \mu \mathrm{m}$ in diameter, are clustered just below the nucleus (Fig. 13-15). The dense bodies are filled with foamy or dense globules (Fig. 12f). In Segments II, III, IV and V, small round or elongated dense bodies, about $0.1 \mu \mathrm{m}$ wide, with amorphous contents, are scattered throughout the cytoplasm (Fig. 4, 5, 8, 12). In summary, the dense bodies are seen in the supra-
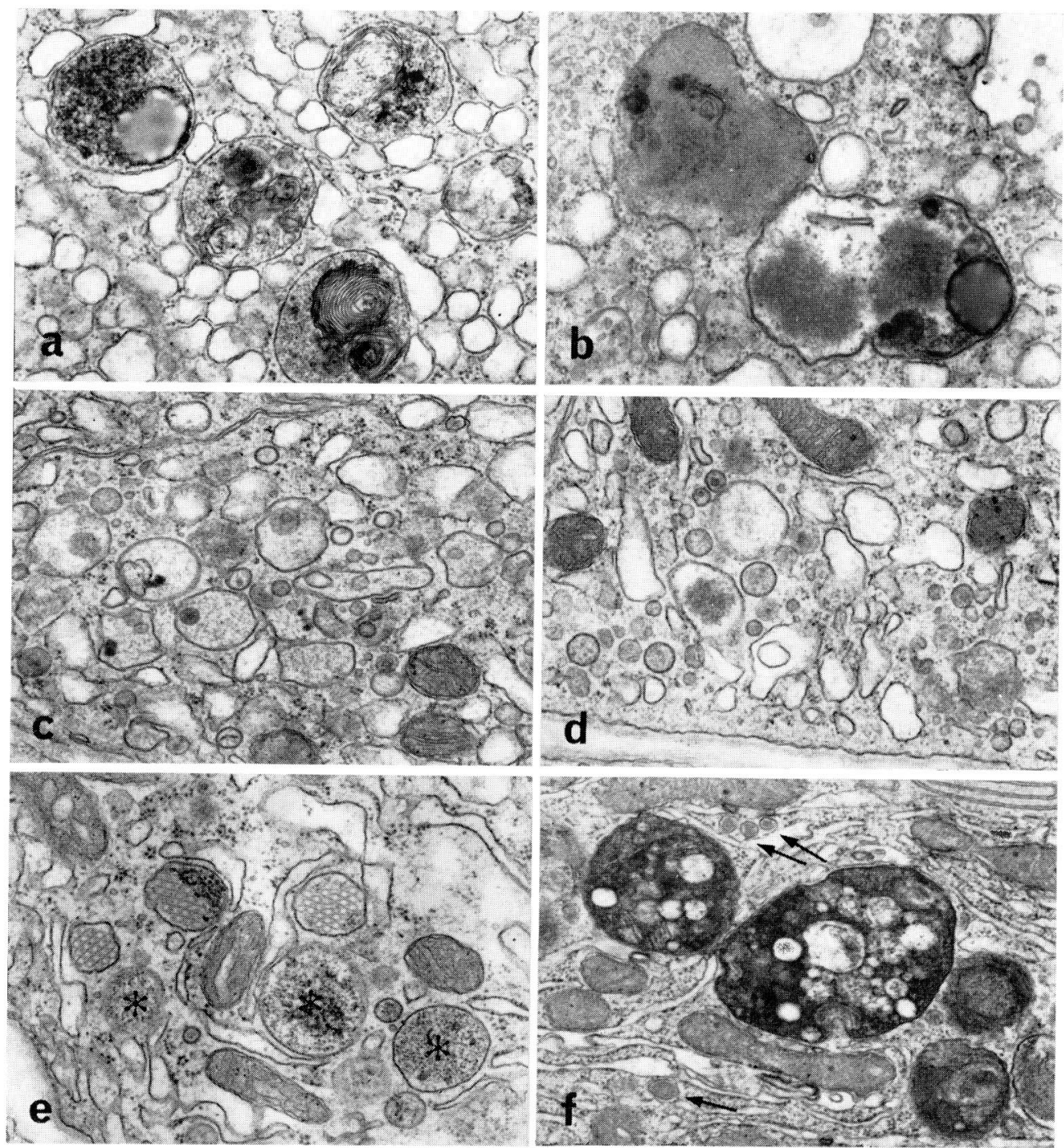

Fig. 12. Dense bodies. a. Supranuclear cytoplasm of the principal cell in Segment I shows dense bodies containing granules, myelin figures, and lipids. b. Dense bodies in the supranuclear cytoplasm of the principal cell in Segment II contain flocculent material. c and d. Infranuclear cytoplasm of the principal cells in Segment III. Dense bodies containing material of low density are variable in size and accumulated near the basal cell surface (lower). e. Infranuclear cytoplasm of the principal cell in Segment IV. Dense bodies containing granules (asterisks) and three inclusions containing a bundle of tubules are visible. $f$. Infranuclear cytoplasm of the principal cell in Segment V. Dense bodies contain foamy figures. Arrows indicate small dense bodies with amorphous contents. $\times 21,000$ 


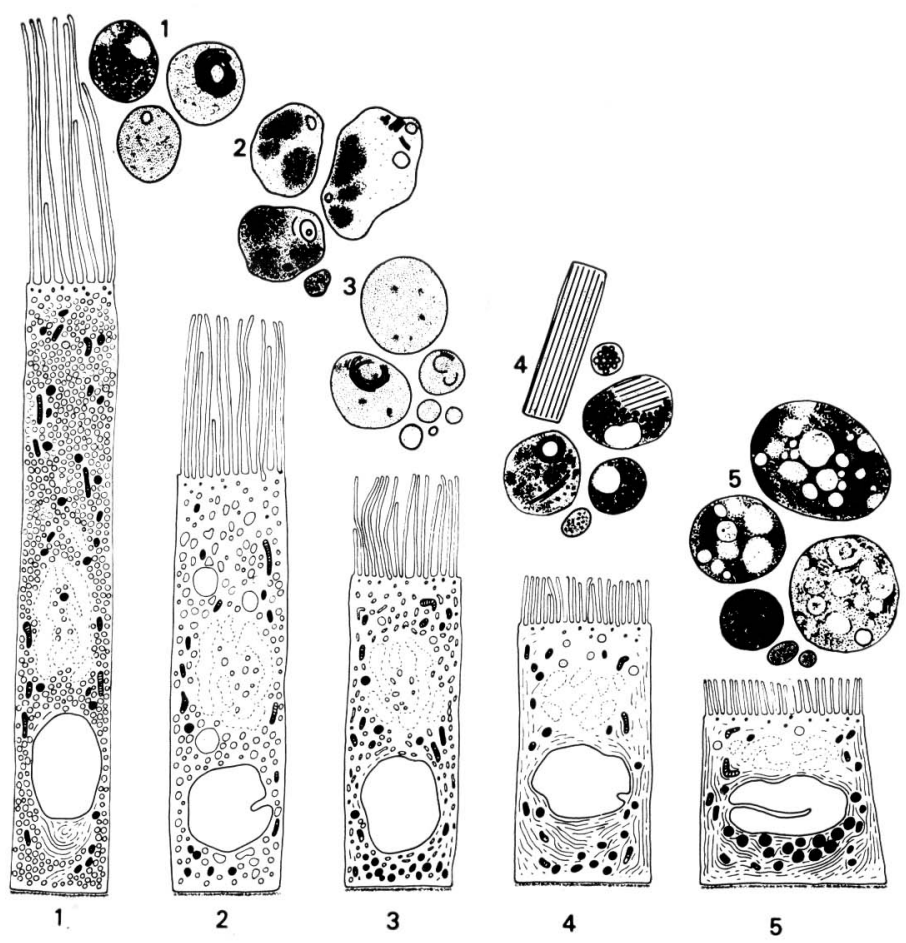

Fig. 13. Diagram showing the shape and distribution of dense bodies in the principal cells in Segments I to V (1-5). In each cell, the dense bodies are filled with black.

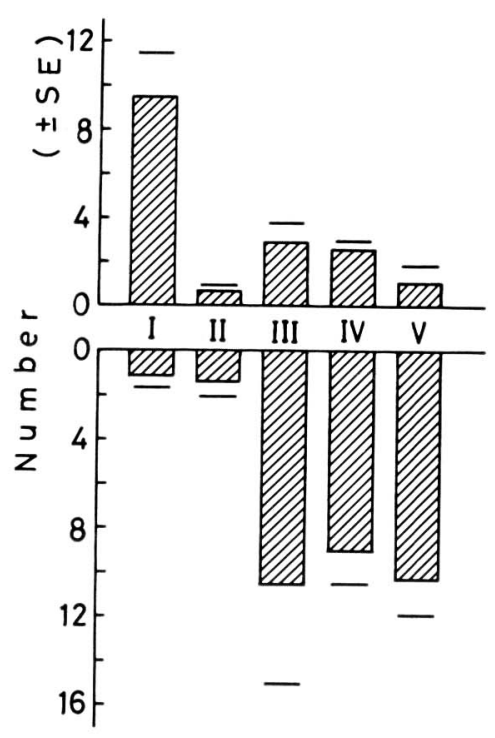

Fig. 14. Number of dense bodies in the supranuclear cytoplasm (top) and infranuclear cytoplasm (bottom) of each principal cell in Segments I to $\mathrm{V}$.

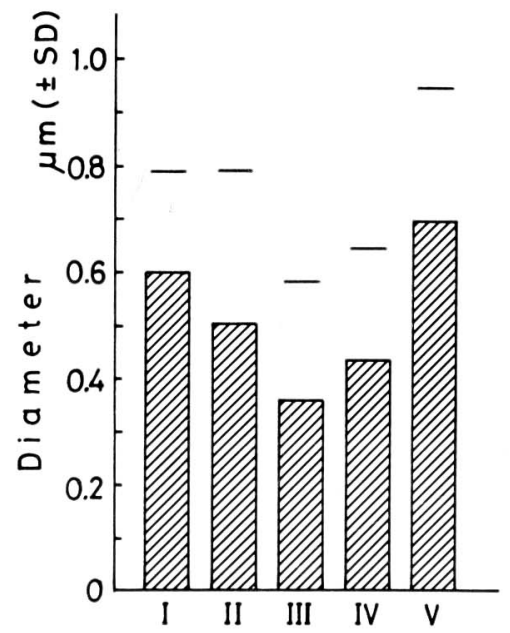

Fig. 15. Size of dense bodies in the principal cells in Segments I to V. 
nuclear cytoplasm in Segment I and in the infranuclear cytoplasm in Segments III, IV and V. Few dense bodies are found in Segment II.

Vesicles in the apical cytoplasm (Fig. 16, 17, Table 1): The apical cytoplasm just under the luminal surface lacks the endoplasmic reticulum and mitochondria, but contains round coated vesicles (Fig. 16). The coated vesicles are of two types, small and large. The small ones are about $50 \mathrm{~nm}$, and the large ones are generally about $100 \mathrm{~nm}$, being up to $250 \mathrm{~nm}$ in diameter (Fig. 16, 17). In Segments I, II and III, the principal cells contain both small and large vesicles, though the large vesicles are more numerous than the small ones (Fig. 17, Table 1). In Segments IV and V, most of the coated vesicles are of the small type (Fig. 17, Table 1). In Segment IV, the coated vesicles are very numerous (Table 1 ).

The luminal surface occasionally has coated invaginations or opened coated vesicles between the adjacent stereocilia (Fig. 16). The invaginations have almost the same diameters as the large coated vesicles in Segments I, II and III, and the small coated

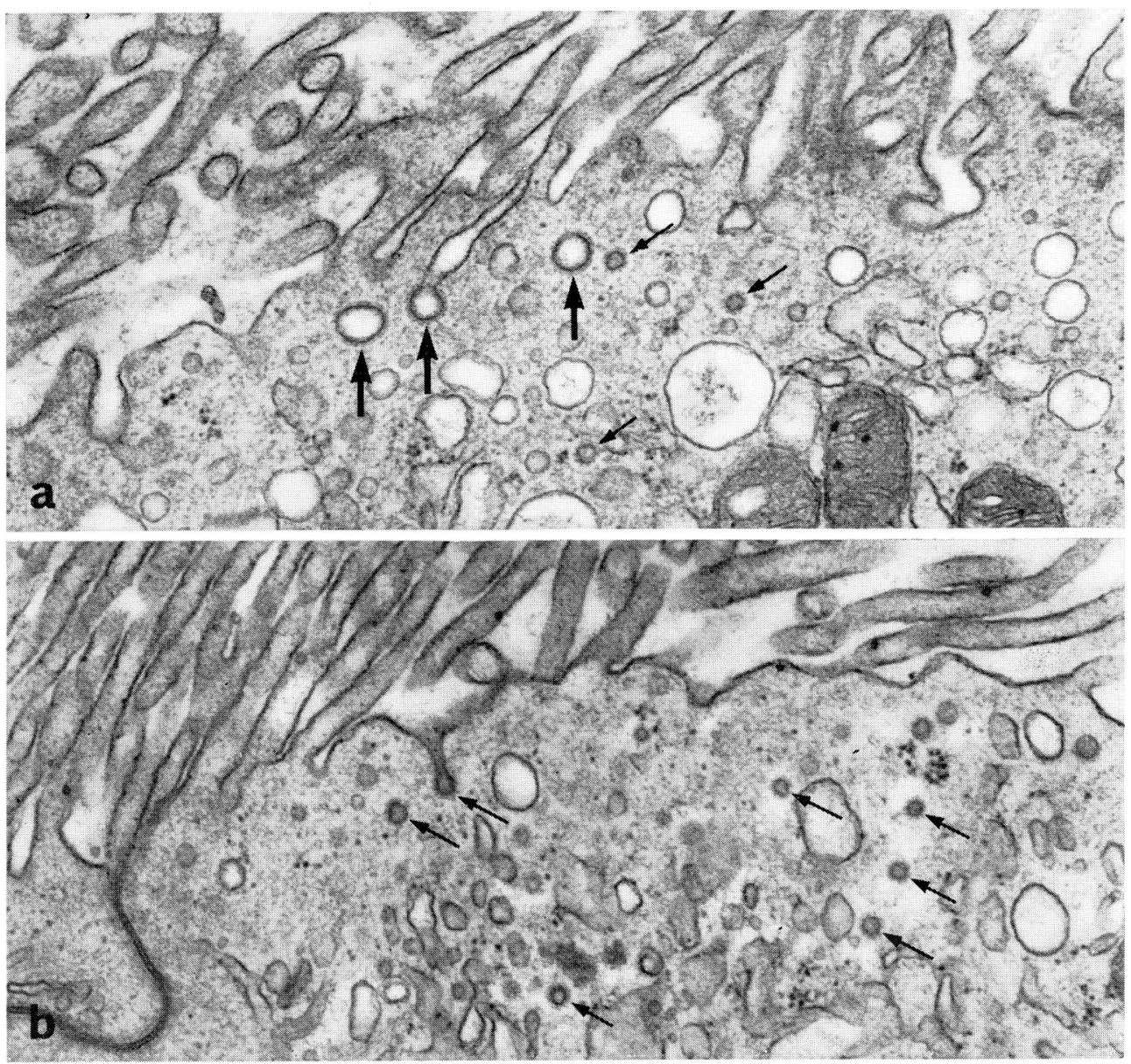

Fig. 16. Apical cytoplasm of the principal cells. a. Segment II. Thick arrows indicate large coated vesicles or coated invaginations of the luminal surface. Thin arrows show small coated vesicles. Non-coated vesicles appear similar in size to coated vesicles. b. Segment IV. Arrows indicate small coated vesicles and invaginations of the luminal surface. $\times 36,000$ 


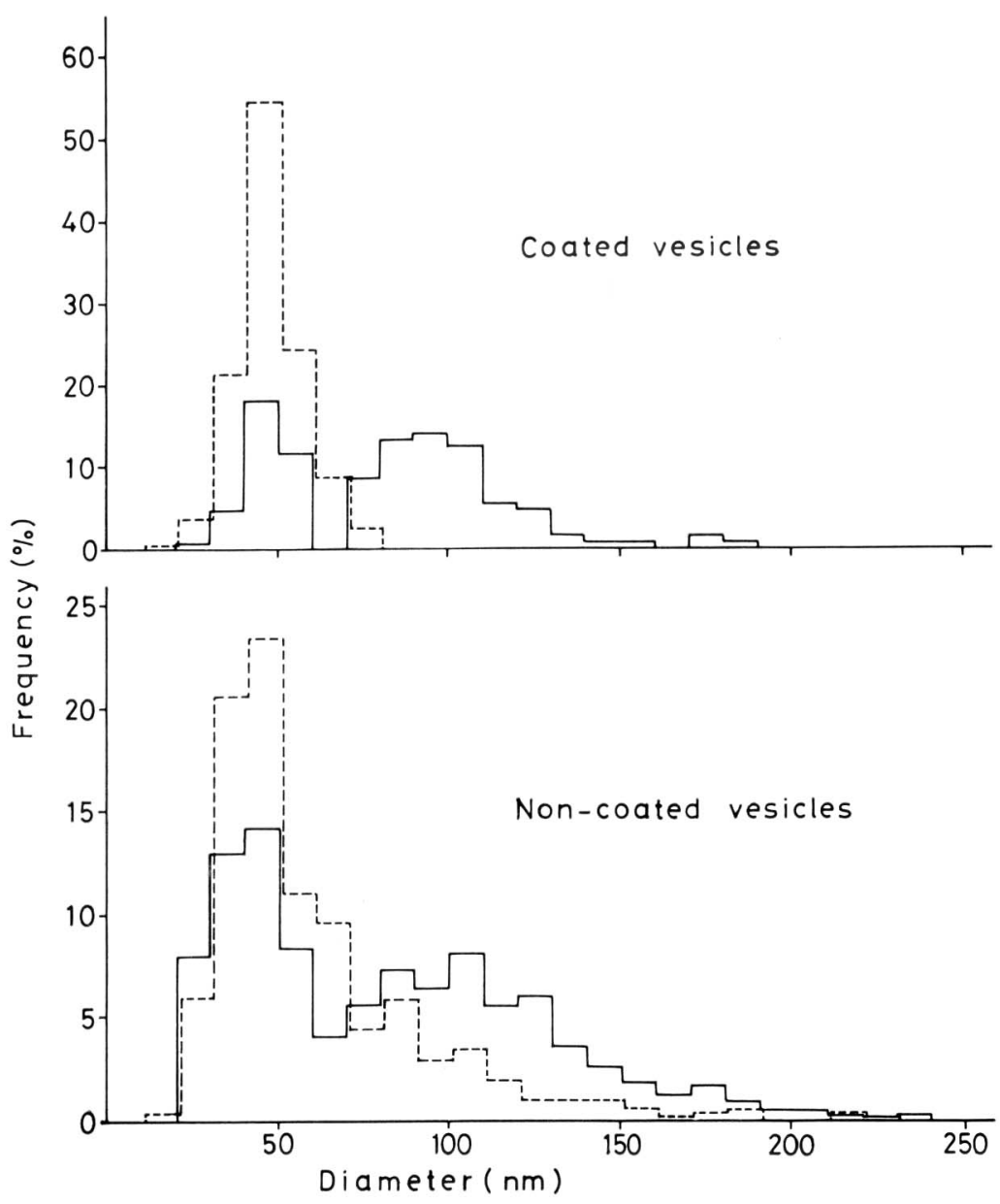

Fig. 17. Size distributions of coated vesicles and non-coated vesicles in the apical cytoplasm of the principal cells in Segment III (solid lines) and Segment IV (broken lines). Vesicles in Segment III are of two types, small and large. Vesicles in Segment IV are of the small type.

Table 1. Number of vesicles in the apical cytoplasm and invaginations of the luminal cell membrane

\begin{tabular}{lcccccc}
\hline Segment & & I & II & III & IV & V \\
\hline \multirow{2}{*}{ Coated vesicles } & S & 6.1 & 5.8 & 7.2 & 31.4 & 12.0 \\
& L & 8.3 & 13.9 & 13.1 & 0.8 & 2.2 \\
\hline \multirow{2}{*}{ Non-coated vesicles } & S & 20.2 & 40.3 & 48.6 & 81.3 & 49.6 \\
& L & 41.9 & 36.2 & 53.9 & 20.8 & 22.2 \\
\hline Coated invaginations & & 5.7 & 8.1 & 10.8 & 4.6 & 7.4 \\
\hline
\end{tabular}

For vesicles, number per a unit area of $10 \mu \mathrm{m}^{2}$ was obtained. Vesicles were classified into small types $(\mathrm{S})$, measuring less than $75 \mathrm{~nm}$ in diameter, and large types (L), measuring more than $75 \mathrm{~nm}$ in diameter. For invaginations, number per a unit length of $10 \mu \mathrm{m}$ was obtained. 
vesicles in Segments IV and V (Fig. 16). They are most frequent in Segment III and relatively infrequent in Segment IV (Table 1).

Non-coated round vesicles, similar in size to the coated vesicles, are also seen in the apical cytoplasm, and they are three times or more as numerous as the coated vesicles (Fig. 17, Table 1).

\section{DISCUSSION}

It is generally known that spermatozoa aquire the capacity for fertilization during passage through the proximal region of the epididymal duct and are then stored in the distal region of the duct (see reviews by BedFord, 1975; Hamil ton, 1975). Thus, it is likely that the functional maturation of spermatozoa is mediated via their surrounding fluid within the lumen of the duct. Based on the cytological features of the principal cells lining the duct, the epididymal duct has been divided into a number of segments; four segments in the dog, six in the rat, horse, sheep and bull, and eight in man and the rabbit (Hammar, 1897; Reid and Cleland, 1957; Nicander, 1957, 1958; Holstein, 1969). In the mouse five segments have been distinguished (TAKANO, 1980).

The epididymal fluid contained in the duct has been reported to be regionally different in chemical composition, and this difference has been thought to be due to that in the functional activity of the epithelium in the different segments (CRABO and Gustafsson, 1964; Levine and Marsch, 1971). The fine structure of the principal cells, particularly the marked development of the cell organelles, suggests that the cells are very active in secretory and absorptive functions (HoFfer et al., 1973; RAmos and Dym, 1977; Flickinger et al., 1978; Jones et al., 1979; Nicander and Plöen, 1979). At present, the principal cells are known to secrete certain compounds including glycoprotein or protein (Lea et al., 1978; Olson and Hamilton, 1978; Faye et al., 1980; Moore, 1980). The well developed rough endoplasmic reticulum and Golgi apparatus are interpreted as cytologic features concerned with the secretory activity (HOFFER et al., 1973; JonES et al., 1979; FAIN-MAurEL et al., 1981).

On the other hand, it has also been accepted that the principal cells are functionally absorptive and that features such as the luminal surface invaginations, coated vesicles, multivesicular bodies, and dense bodies are associated with the absorptive function of the cells (Friend and Farquhar, 1967; Moniem and Glover, 1972; Moore and Bedford, 1979). Tracer studies have demonstrated that the principal cells absorb India ink, ferritin, colloidal mercuric sulphate, or horse radish peroxidase from the lumen, and that the tracers are transported by the pinocytotic vesicles into the multivesicular bodies and dense bodies (Burgos, 1964; Nicander, 1965; Moniem and Glover, 1972; Moore and BEDFORD, 1979). The principal cells in Segment II have especially large multivesicular bodies, which appear to become dense bodies. The multivesicular bodies and dense bodies contain acid phosphatase which seems to hydrolyze the absorbed materials (Friend, 1969; Moniem and Glover, 1972).

Though the ultrastructure of the principal cells has been well documented in relation to the secretory and absorptive functions in the different segments of the duct, the relation between ultrastructural and functional differences has not entirely been clarified. The present results confirm that the five segments can be distinguished by electron microscopy as well as light microscopy (TAKANO, 1980) and that the principal cells differ in ultrastructural details in the different segments.

The endoplasmic reticulum significantly varies in shape and distribution between 
the proximal region consisting of Segments I, II and III, and the distal region composed of Segments IV and V. The number of luminal surface invaginations and coated vesicles in the apical cytoplasm of the proximal and distal regions also differ. These may reflect the functional significances of the two regions; the proximal region is thought to serve for the maturation of spermatozoa and the distal region for the storage of mature spermatozoa.

Segment I, commonly referred to as the initial segment, has been known to be very active in absorption of the testicular fluid (Levine and MARsch, 1971). The multivesicular bodies and dense bodies in the supranuclear cytoplasm in this segment seem to be involved in this absorptive activity. It has been also indicated, on the other hand, that protein is actively secreted in the initial segment (KAŇKA and KoPEČNÝ, 1977; KopečnÝ and PeCH, 1977). The marked development of the endoplasmic reticulum appears to be dependent on the testicular fluid contained in the lumen of this segment, because the endoplasmic reticulum regresses after efferent duct ligation (FAWCETT and HoFfer, 1979; MOORE and BEDFord, 1979). The finding that the capillary net work surrounding the duct is more marked in the initial segment, Segment I, than in the other segments (Setchell et al., 1964; TAKano, 1980) also suggests that Segment I is metabolically very active. Thus, Segment I, as has been extensively investigated (Hoffer et al., 1973; MOORE and BEDFORD, 1979), is considered to be a functionally specialized region in the epididymal duct.

It has been thought that specific epididymal glycoprotein is important for providing the fertilizing ability to spermatozoa (LEA et al., 1978; Olson and Hamilton, 1978; MoORE, 1980). Such glycoprotein has recently been isolated and purified in the rabbit and rat epididymis and demonstrated to be produced by the epithelial cells in the region just distal to the initial segment and to be bound to spermatozoa (LEA et al., 1978; FAYE et al., 1980; MOORE, 1980). In the mouse, as reported in a previous paper, the principal cells in Segment II secrete a PAS-positive material that is considered to contain glycoprotein to be bound to spermatozoa ( $\mathrm{BBE}$ et al., 1982a). The vesicular rough endoplasmic reticulum in the principal cells in this segment may be involved in the secretory activity of the specific glycoprotein.

The principal cells in Segment III are also characterized by an abundance of vesicular rough endoplasmic reticulum. The luminal surface of the cells in Segments II and III shows a strong alkaline phosphatase reaction (TAKANO, 1980) which seems to be associated with the cellular secretory activities (BERN, 1949, MANEely, 1955). However, the two segments are distinguished from each other by PAS staining in light microscopy (TAKANo, 1980) and the appearance of the endoplasmic reticulum under the electron microscope. Thus it is likely that Segments II and III differ in nature of the secretion. On the other hand, the occurrence of the multivesicular bodies and dense bodies in the principal cells of Segments II and III suggests that these segments are absorptive as well as secretory in function. The multivesicular bodies and dense bodies significantly differ in features between the two segments. In Segment II the principal cells contain considerable amounts of large multivesicular bodies but almost no dense bodies. In Segment III many dense bodies, which are heterogenous in appearance, are located in the infranuclear cytoplasm as in Segments IV and V. The dense bodies are generally thought to represent various stages of destruction of the ingested material (Jones et al., 1979). Dense bodies with quite amorphous contents are seen close to the basal cell membrane (RAmos and Dym, 1977). These findings may indicate an endocrine function of the cells, as speculated Ramos (1980).

Segments IV and V are similar in ultrastructural details. The well developed 
organelles in the principal cells suggest that the two segments functionally participate not only in the storage of spermatozoa but also in functional interaction with the luminal contents. As reported previously (ABE et al., 1982a), the PAS-positive material that is secreted in Segment II and remains unbound to spermatozoa is absorbed in Segment IV. The multivesicular bodies and dense bodies may be involved in the absorptive activity. In addition, the peculiar tubule-containing inclusions which appear only in Segment IV may be concerned with a specific function, i.e., absorption of the glycoprotein in this segment (ABE et al., 1982a).

The dense bodies in Segment V show a particular appearance. In the rabbit epididymal duct, lipofuscin or pigment-like granules have been observed in the terminal segment, and they have been regarded as residual bodies of lipids released from spermatozoa, because spermatozoa contain unsaturated phospholipid which decreases in amount during passage through the epididymal duct (VogLma Yr, 1975; Jones and MANN, 1977; JonEs et al., 1979). It is possible that the membranous structures and lipid droplets in the dense bodies in Segment IV represent ingested lipid. In addition, the coated vesicles in Segments IV and V are different from those in the more proximal segments. Thus, they appear to be also involved in a specific absorptive function in the distal segments.

In summary, the ultrastructure of the principal cells of the mouse epididymal duct suggests that the principal cells have specific functions for each segment.

\section{REFERENCES}

Abe, K., H. Takano and T. Ito: Response of the epididymal duct in the corpus epididymidis to efferent or epididymal duct ligation in the mouse. J. Reprod. Fertil. 64: 69-72 (1982a). mouse ligated epididymis. Biol. Reprod. 26: 501-509 (1982b).

: Tubule-containing inclusions in the epithelial cells of the mouse epididymal duct. Arch. histol. jap. 46: 69-77 (1983).

Bedford, J. M.: Maturation, transport and fate of spermatozoa in the epididymis. In: (ed. by) D. W. Hamilton and R. O. Greep: Handbook of physiology, Sec. 7, vol. V. Male reproductive system. American Physiological Society, Washington, D. C., 1975. (p. 303-317).

Bern, H.: The distribution of alkaline phosphatase in the genital tract of male mammals. Anat. Rec. 104: 361-377 (1949).

Burgos, M. H.: Uptake of colloidal particles by cells of the caput epididymidis. Anat. Rec. 148: 517-525 (1964).

Crabo, B. and B. Gustafsson : Distribution of sodium and potassium and its relation to sperm concentration in the epididymal plasma of the bull. J. Reprod. Fertil. 7: 337-345 (1964).

Fain-Maurel, M. A., J. P. Dadoune and M. F. Alfonsi : High-resolusion autoradiography of newly formed proteins in the epididymis after incorporation of tritiated amino acids. Arch. Androl. 6: 249-266 (1981).

Fawcett, D. W. and A. P. Hoffer.: Failure of exogenous androgen to prevent regression of the initial segments of the rat epididymis after efferent duct ligation or orchidectomy. Biol. Reprod. 20: 162-181 (1979).

Faye, J. C., L. Duguet, M. Mazzuca and F. Bayard : Purification, radioimmunoassay, and immunohistochemical localization of a glycoprotein produced by the rat epididymis. Biol. Reprod. 23: 423-432 (1980).

Flickinger, C. J., S. S. Howards and H. F. English : Ultrastructrural differences in efferent ducts and several regions of the epididymis of the hamster. Amer. J. Anat. 152: 557-586 (1978). 
Friend, D. S.: Cytochemical staining of multivesicular body and Golgi vesicles. J. Cell Biol 41: 269-279 (1969).

Friend, D. S. and M. G. Farquhar: Functions of coated vesicles during protein absorption in the rat vas deferens. J. Cell Biol. 35: 357-376 (1967).

Glover, T. D. and L. Nicander: Some aspects of structure and function in the mammalian epididymis. J. Reprod. Fertil., Suppl. 13: 39-50 (1971).

Hamilton, D. W.: Structure and function of the epithelium lining the ductuli efferentes, ductus epididymidis and ductus deferens in the rat. In: (ed. by) D. W. Hamilton and R. O. Greep: Handbook of physiology, Sec. 7, vol. V. Male reproductive system. American Physiological Society, Washington, D. C., 1975. (p. 259-301).

Hammar, J. A.: Ueber Secretionserscheinungen im Nebenhoden des Hundes. Arch. Anat. Entw.Gesch., Suppl.: 1-42 (1897).

Hoffer, A. P. and J. Greenberg: The structure of the epididymis, efferent ductules and ductus deferens of the guinea-pig: a light microscope study. Anat. Rec. 90: 659-678 (1978).

Hoffer, A. P., D. W. Hamilton and D. W. Fawcett: The ultrastructure of the principal cells and intraepithelial leucocytes in the initial segment of the rat epididymis. Anat. Rec. 175: 169-202 (1973).

Holstein, A. F.: Morphologische Studien am Nebenhoden des Menschen. Zwangl. Abhandl. Gebiet norm. pathol. Anat. 20: 1-91 (1969).

Jones, R., D. W. Hamilton and D. W. Fawcett : Morphology of the epithelium of the extratesticular rete testis, ductuli efferentes and ductus epididymidis of the adult male rabbit. Amer. J. Anat. 156: 373-400 (1979).

Jones, R. and T. Mann : Damage to ram spermatozoa by peroxidation of endogenous phospholipids. J. Reprod. Fertil. 50: 261-270 (1977).

Kan̆ka, J. and V. Kopečný : A autoradiographic study of macromolecular synthesis in the epithelium of the ductus epididymidis in the mouse. I. DNA, RNA and protein. Biol. Reprod. 16: 421-427 (1977).

Kopečný, V. and V. Pech: An autoradiographic study of macromolecular syntheses in the epithelium of the ductus epididymidis in the mouse. II. Incorporation of L-fucose-1- ${ }^{3} \mathrm{H}$. Histochemistry 50: 229-238 (1977).

Lea, O. A., P. Petrusz and F. S. French : Purification and localization of acidic epididymal glycoprotein (AEG): a sperm coating protein secreted by the rat epididymis. Int. J. Androl., Suppl. 2: 592-607 (1978).

Levine, N. and D. L. Marsch : Micropuncture studies of the electrochemical aspects of fluid and electrolyte transport in individual seminiferous tubules, the epididymis and the vas deferens in rats. J. Physiol. 213: 557-570 (1971).

Maneely, R. B.: The distribution of polysaccharide complexes and of alkaline glycerophosphatase in the epididymis of the rat. Acta anat. 24: 314-329 (1955).

Moniem, K. A. and T. D. Glover : Comparative histochemical localization of lysosomal enzymes in mammalian epididymides. J. Anat. 111: 437-452 (1972).

Moore, H. D. M.: Localization of specific glycoproteins secreted by the rabbit and hamster epididymis. Biol. Reprod. 22: 705-718 (1980).

Moore, H. D. M. and J. M. Bedford : The differential absorptive activity of epithelial cells of the rat epididymis before and after castration. Anat. Rec. 193: 313-328 (1979).

Nicander, L.: On the regional histology and cytochemistry of the ductus epididymis in rabbit. Acta morphol. neerl.-scand. 1: 99-118 (1957). : Studies on the regional histology and cytochemistry of the ductus epididymidis in stallion, rams and bulls. Acta morphol. neerl.-scand. 1: 337-362 (1958).

: An electron microscopical study of absorbing cells in the posterior caput epididymidis of rabbits. Z. Zellforsch. 66: 829-847 (1965).

Nicander, L. and T. D. Glover: Regional histology and fine structure of the epididymal duct in the golden hamster (Mesocricetus auratus). J. Anat. 114: 347-364 (1973).

Nicander, L. and L. Plöen: Studies on regional fine structure and function in the rabbit epididymis. Int. J. Androl. 2: 463-481 (1979). 
Olson, G. E. and D. W. Hamilton : Characterization of the surface glycoproteins of rat spermatozoa. Biol. Reprod. 19: 26-35 (1978).

Ramos, A.S., Jr.: Ultrastructural and histochemical observations on the principal cells of monkey epididymis. Arch. Androl. 5: 159-168 (1980).

Ramos, A. S., Jr. and M. Dym : Fine structure of the monkey epididymis. Amer. J. Anat. 149: 501532 (1977).

Reid, B. L. and K. W. Cleland : The structure and function of the epididymis. I. The histology of the rat epididymis. Austral. J. Zool. 5: 223-246 (1957).

Setchell, B. P., G. M. H. Waites and A. R. Till : Variations in flow of blood within the epididymis of the sheep and rat. Nature 203: 317-318 (1964).

Takano, H.: Qualitative and quantitative histology and histogenesis of the mouse epididymis, with special emphasis on the regional difference. (Japanese text with English abstract). Acta anat. nippon. 55: 573-587 (1980).

Takano, H., K. Abe and T. Ito: Changes in the mouse epididymis after ligation of the ductuli efferentes or proximal epididymal duct: qualitative and quantitative histological studies. (Japanese text with English abstract). Acta anat. nippon. 56: 79-90 (1981).

Voglmayr, J. K.: Metabolic changes in spermatozoa during epididymal transit. In: (ed. by) D. W. Hamilton and R. O. Greep: Handbook of physiology, Sec. 7, vol. V. Male reproductive system. American Physiological Society, Washington, D. C., 1975. (P. 437-451).

\author{
阿部和厚 \\ 厂060 札幌市北区北15条西 7 丁目 \\ 北海道大学医学部 \\ 解剖学第三講座
}

Dr. Kazuhiro ABE

Department of Anatomy

Hokkaido University School of Medicine

Sapporo, 060 Japan 